\title{
SEXUAL BEHAVIOUR AND REPRODUCTIVE HEALTH OF WOMEN IN NORTH SULAWESI PROVINCE: A SECONDARY DATA ANALYSIS
}

\author{
Indriani Yauri ${ }^{1 *}$, Brigitte Inez Maitimo ${ }^{2}$, Vervando J. Sumilat ${ }^{3}$, Junita J J. Koilam ${ }^{4}$ \\ ${ }^{1,3,4}$ Catholic University De La Salle Manado \\ ${ }^{2}$ Research Unit of National Population and Family Planning (BKKBN) of North Sulawesi Province. \\ Email*: iyauri@unikadelasalle.ac.id
}

\begin{abstract}
Introduction: Although health promotion strategies have been made to promote reproductive health, women's reproductive health problems have not dropped significantly. This study aimed to examine the relationship between early sexual behavior and reproductive health of women of reproductive-aged 15-49 years old for North Sulawesi Province, Indonesia. Methods: Descriptive correlational design was used to examine the relationship between the age of first sexual intercourse and pregnancy complications, decision making about the use of birth control, and knowledge about HIV-AIDS. Data were obtained from 585 women aged 15-49-year-old selected from the 2017 Indonesia Demographic and Health Survey (SDKI 2017). Results: Cramer's V correlation coefficient showed a strong correlation between age at first sexual intercourse and pregnancy complications and moderate correlation between decision making about the use of birth control, and knowledge about HIV-AIDS. Forty percent of sexually active women were 10-19 years old. In addition, decisions about the use of contraceptive strategies among those ages have the potential to be not users in accordance with rational contraception use because they might not seek health workers' advice. This study also found a low proportion of women understood HIV transmission. Conclusions: Findings from this study affirm the hypothesis that women's sexual behavior correlates with their reproductive health. Therefore, improving sexual behavior may improve reproductive health. These findings also may be used to inform the effectiveness of the implemented reproductive health programs in North Sulawesi Province. Several culturally sensitive strategies are recommended to overcome problems and improve reproductive health.
\end{abstract}

Keywords: contraception; HIV-AIDS; pregnancy; reproductive health; sexual behavior

\section{INTRODUCTION}

Early sexual behavior is one of the causes of reproductive health problems in adolescents. The first age to have sex can be related to the age of married couples. Women who marry first at a young/early age tend to start having children at their young age (BKKBN, 2017; Djamilah, D., 2015). Thus, early marriage can increase fertility rate since the younger is a woman marry, the longer is women's reproductive period. However, teenage mothers are more at risk for health problems and death related to childbirth compared to older women (WHO, 2018; Woog \& Kågesten, 2017). For some other teens, unwanted pregnancy leads to abortion (Djamilah, D., 2015). The Indonesian Demographic and Health Survey (IDHS) in 2017 have portrayed important events related to Population, Family Planning, and Family Development. However, only limited studies examine women's sexual behavior and their reproductive health in the region of North
Sulawesi Province. Therefore, it is deemed necessary to investigate whether there is a significant relationship between sexual behavior and reproductive health of women aged 15-49 years old.

Early marriage may lead to social problems. Childbirth at a young age reduces their chances of continuing education or finding work (MacPhail et al., 2007; Nugraheni et al., 2018; Woog \& Kågesten, 2017). Reasonably, findings from the 2017 Indonesia Demographic and Health Survey (IDHS) show that $9 \%$ of women aged 15-19 are mothers: $6 \%$ had given birth, and $4 \%$ were pregnant with their first child. Gender disparity has resulted in adolescents and young women being excluded (Wattimena et al., 2020; WHO, 2018). Discrimination and violence are also frequently reported among young mothers.

In addition, sexual intercourse in adolescents also increases sexually transmitted diseases. In Indonesia, in 2006, there were cases of AIDS in adolescents aged 15-19 years old totaling 222 cases (2.7\%), and aged 5-14 
years old amounted to 22 cases $(0.26 \%)$ (BKKBN, 2012) Manado City, Bitung City. Minahasa Regency was still the region with the highest number of HIV and AIDS cases until 2016 (Dinkes, 2015). Tulloch \& Kaufman (2013) reported Chlamydia infection in the majority of adolescent girls aged 15-19 years old. Furthermore, among married women and men aged 15-24 years old in North Sulawesi Province, $18.2 \%$ of women have STIs or STI symptoms (SDKI, 2017).

The prevalence of early sexual activity tends to increase almost all over the world. Research by the Youth Risk Behavior Survey in grades 9 - 12 in America shows that $46 \%$ of adolescents have had sexual intercourse, and $5.9 \%$ had sexual intercourse for the first time before age 13 (Finner \& Philibin, 2013). Similarly, premarital sexual activity in adolescents in Indonesia is also increasing. According to 2017 Indonesian Demographic and Health Survey (Berliana.,Utami., and Effendi., 2018; BKKBN, 2017), although the median age of first marriage for married women age 25-49 was 21 years old and married men aged 25-54 are 24 years old, 50 percent of the women, married women and married men in the age group had committed early sexual intercourse.

Improving the usage of contraception methods can promote women's reproductive health. Family Planning (KB) is done through the use of contraception methods. Providers of family planning services are required to educate the family on how to choose the most suitable method. Furthermore, an accurate physical examination is also crucial before determining the rational contraception methods for the family (Harnan.,Marlian., Kursani, 2019) Family planning participation is the joint responsibility of husband and wife (Harnan.,Marlian., Kursani, 2019;BKKBN, 2017). Thus, the decision to use family planning methods is a choice of husband and wife after having adequate information and health examination.

Reproductive health is one of the agendas of women's health in the world.
According to the World Health Organization (WHO, 2018), reproductive health is a complete physical, mental and social condition and not just the absence of disease or weakness, in all matters relating to the reproductive system and its functions and processes. According to BKKBN (2001), Reproductive Health is physical health, mental health and social welfare as a whole in all matters relating to the system and function and process of reproduction and not just conditions that are free from disease and disability (Harnan.,Marlian., Kursani, 2019;BKKBN, 2017). The scope of reproductive health services according to the 1994 International Conference on Population and Development (ICPD) in Cairo consists of maternal and child health, family planning, prevention and management of sexually transmitted infections including HIV / AIDS, adolescent reproductive health, prevention and management of complications of abortion, prevention and handling of infertility, elderly reproductive health, early detection of reproductive tract cancers and other reproductive health such as sexual violence, female circumcision and so on (Badan Kependudukan Dan Keluarga Berencana Nasiona, 2015; InfoDaTin, 2015). Pregnancy complication is one indicator of disruption of reproductive health status in aspects of maternal health. Pregnancy complications are health problems or disorders that often occur during pregnancy and can have an impact not only on the health of the mother but also on newborns.

\section{METHODS}

Descriptive Correlational Study research design was used to determine the relationship between sexual behavior (measured by the age of first sexual intercourse) and reproductive health (measured by pregnancy complications, decision making about the use of contraception and knowledge about HIV-AIDS) of women aged 15-49 years old reported in the 2017 Indonesia Demographic and Health Survey (SDKI 2017). 
The population in this study was 585 women aged 15-49 years old living in North Sulawesi Province. Women aged $>49$ years old were excluded. The number of participants who completed the survey questionnaires was different for each measured variable. In order to obtain an accurate reflection of the population, the survey data were weighted. The statistical adjustment in this study employed total age as the auxiliary variable.

Descriptive and inferential analysis was conducted to test the hypotheses in this study, using SPSS 22. The results are presented in tabular forms. Inferential analysis was performed using chi-square for an independence test to answer the research hypothesis. The strength of the association was determined using Cramer's V correlation coefficient using three categories: 1) weak association: 0.06; moderate association: 0.17; and significant associations: 0.29. A 95\% confidence level $(\alpha<0.05)$ was used to determine the relationship. Protection towards individual rights was done by obtaining ethical contentment from the Health Research Ethics Commission (KEPK) of the Health Ministry of Health, Manado, through the Ethical Approval No. 439 / KEPK / IX / 2019.

\section{RESULTS}

Demographic characteristics of the respondents showed that most respondents in the 2017 IDHS were at the age of 40-44 years old, amounting to $17.1 \%$. In 2012, the highest age was 15-19 years old, $16.5 \%$, while in 2007 it was $30-34$ years old, which was $21.4 \%$. The increase in the proportion of women of reproductive age in the 15-19 age group occurred in 2007-2017 by almost $14 \%$. Conversely, there was a decrease in the number of women of reproductive age in the 30-34 years of age group by $8.4 \%$. Moreover, the majority of respondents' education from 20072017 is a secondary school that is $61-65 \%$. An interesting phenomenon in this category is that there are no more women of reproductive age who did not attend high school in 2017.
Characteristics of the employment of the participants depicted most respondents in 2017, 2012, and 2007 were unemployed, then followed by sellers. Respondents who did not work totaled $52.5 \%$ in 2017 , in 2012, a total of $50.8 \%$, and in 2007 amounted to $56.4 \%$. This figure is followed by the type of work as a seller of approximately $15-20 \%$ of the total women of reproductive age in the 2007-2017 period. In particular, working as a farmer decreased from 2007-2017 by $6.1 \%$.

The trend in the first age of sexual relationship (AFSI) in women of reproductiveaged 15-49 years old indicated that respondents who had early sexual relations were mostly aged $15-19$ years old $(35 \%$ - 41\%) followed by ages 20-24 years old (24\% - 37\%). Although the number is smaller, the percentage of respondents who have sexual intercourse for the first time at the age of 10-14 years old increases from $3 \%$ in 2012 to $3.6 \%$ in 2017. On the contrary, there was a decrease of $6 \%$ in the number of respondents who did not have sexual intercourse, from approximately $28 \%$ in 2012 to $22 \%$ in 2017 . The results from the $2007-$ 2017 IDHS indicate that almost $40 \%$ of women have sexual intercourse before the age of 20 years. The trend of First Marriage Age (FMA) in women of reproductive-aged 15-49 years old showed that the highest FMA in 2007-2017 is at the age of 15-19 years early, which is approximately 33\% -40\%. However, in 2017 there were still women of reproductive age who married for the first time at the age of 10-14 years, as many as $2.6 \%$. On the contrary, in the same year, there were $3.6 \%$ of women who committed sexual intercourse at the age of 1014 years. Furthermore, from 2007-2017, it was identified a decrease in the number of women who first married at the age of 20-24 years old from approximately $41 \%$ to $26.5 \%$. The data above shows that until 2017, marriages occurred at the risk age group (below 20 years old) by $37 \%$. Results from this study have depicted $40 \%$ of early sexual activities among women of reproductive below 20 years old, but only $37 \%$ of marriage are reported from 2007 2017. 
To be able to function as an independent variable, a multicollinearity check is performed on the first sexual intercourse and FMA variables. This is done to see whether the two independent variables are highly correlated or not. The existence of multicollinearity, according to Pallant (2014), will lead to the estimation of unreliable and unstable regression coefficients. Multicollinearity test results showed a strong and positive correlation between the two variables: first sexual intercourse and first marriage age, $r=0.96$, $\mathrm{n}=585, \mathrm{p}<0.000$, which means an increase in the number of first sexual intercourse is associated with an increase in the name of FMAs in each age group. The analysis showed that the relationship strength was 92\% (very strong), which meant that the variations contained in the first sexual intercourse variable could be explained or the same as those found in the FMA variable. In other words, both variables have a $92 \%$ similarity in variation. Based on the multicollinearity test results, it can be concluded that it is necessary to reduce one of the independent variables. For this reason, a variable has been chosen that will be an independent variable in this study, namely the age at first sexual intercourse.

Pregnancy complications are the percentage of pregnancy complications for live births in the past five years. In this study, the rate of respondents who experienced difficulties during pregnancy decreased from 2007 by $10.5 \%$ to 2012 to 9\% and then increased in 2017 to $14.4 \%$. This data shows an increasing trend of pregnancy complications in the 2012-2017 period of $3.9 \%$.

Tabel 1. Pregnancy complications according to women's first age to have sex in 2017

\begin{tabular}{|c|c|c|c|c|}
\hline \multirow{2}{*}{\multicolumn{2}{|c|}{ Age of first sexual intercourse }} & \multicolumn{2}{|c|}{ Pregnancy Complications } & \multirow{2}{*}{ Total } \\
\hline & & Yes & No & \\
\hline \multirow{3}{*}{$10-14$} & $\mathrm{n}$ & 5 & 20 & 25 \\
\hline & $\%$ within Age & $20.0 \%$ & $80.0 \%$ & $100.0 \%$ \\
\hline & $\%$ of Total & $1.1 \%$ & $4.5 \%$ & $5.6 \%$ \\
\hline \multirow{3}{*}{ 15-19 } & $\mathrm{n}$ & 21 & 184 & 205 \\
\hline & $\%$ within Age & $10.2 \%$ & $89.8 \%$ & $100.0 \%$ \\
\hline & $\%$ of Total & $4.7 \%$ & $41.0 \%$ & $45.7 \%$ \\
\hline \multirow{3}{*}{$20-24$} & $\mathrm{n}$ & 20 & 131 & 151 \\
\hline & $\%$ within Age & $13.2 \%$ & $86.8 \%$ & $100.0 \%$ \\
\hline & $\%$ of Total & $4.5 \%$ & $29.2 \%$ & $33.6 \%$ \\
\hline \multirow{3}{*}{$25-29$} & $\mathrm{n}$ & 3 & 42 & 45 \\
\hline & $\%$ within Age & $6.7 \%$ & $93.3 \%$ & $100.0 \%$ \\
\hline & $\%$ of Total & $0.7 \%$ & $9.4 \%$ & $10.0 \%$ \\
\hline \multirow{3}{*}{$30-34$} & $\mathrm{n}$ & 9 & 3 & 12 \\
\hline & $\%$ within Age & $75.0 \%$ & $25.0 \%$ & $100.0 \%$ \\
\hline & $\%$ of Total & $2.0 \%$ & $0.7 \%$ & $2.7 \%$ \\
\hline \multirow{3}{*}{$35-39$} & $\mathrm{n}$ & 6 & 3 & 9 \\
\hline & $\%$ within Age & $66.7 \%$ & $33.3 \%$ & $100.0 \%$ \\
\hline & $\%$ of Total & $1.3 \%$ & $0.7 \%$ & $2.0 \%$ \\
\hline $40-44$ & $\mathrm{n}$ & 1 & 1 & 2 \\
\hline
\end{tabular}


Sexual Behaviour and Reproductive Health of Women ... (Indriani, et.al)

\begin{tabular}{rlrrr} 
& \% within Age & $50.0 \%$ & $50.0 \%$ & $100.0 \%$ \\
& $\%$ of Total & $0.2 \%$ & $0.2 \%$ & $0.4 \%$ \\
\hline \multirow{3}{*}{ Total } & $\mathbf{n}$ & $\mathbf{6 5}$ & $\mathbf{3 8 4}$ & $\mathbf{4 4 9}$ \\
& $\%$ within Age & $14.5 \%$ & $85.5 \%$ & $100.0 \%$ \\
& $\%$ of Total & $14.5 \%$ & $85.5 \%$ & $100.0 \%$ \\
\hline
\end{tabular}

$*$ Weighted 2.8

Based on table 1, 449 women reported their age at first sexual intercourse. The range of age said was 10-44 years old. This was approx $-77 \%$ women from total women in the age of 15-49 years old ( $N=585)$. Reasonably, twenty-three percent of the population had not had sexual intercourse yet (reported in Table 3). It was found that there were still $14.5 \%$ of women of reproductive age who had pregnancy complications in 2017. In fact, $20 \%$ of women within the group of age 10-14 years had experienced pregnancy complications. This was doubled the incidence of women within the group of age 15-19 years (approx. 11\%). The lowest number of pregnancy complication incidence was reported in the 25-29 years old group (approx. 7\%). The highest number of pregnancy complications was in the group of 30-34 years old, amounted to $75 \%$. However, detail complications experienced by the respondents were not available in IDHS 2017.

Chi-square test for independence showed a statistically significant relationship between the age of first sexual intercourse and pregnancy complications, $X^{2}(6, n=449)=$ 63.33, $p=0.000$. The results of this analysis showed a strong association (Cramer's $\mathrm{V}=$ $0.35)$ between the two variables.

Table 2. Decision Making on KB according to women's first age to have sex in 2017

\begin{tabular}{|c|c|c|c|c|c|c|}
\hline \multirow{2}{*}{\multicolumn{2}{|c|}{$\begin{array}{l}\text { Age of first sexual } \\
\text { intercourse (year) }\end{array}$}} & \multicolumn{4}{|c|}{ Decision Makers use Contraceptive } & \multirow{3}{*}{$\begin{array}{r}\text { Total } \\
21\end{array}$} \\
\hline & & \multirow{2}{*}{$\begin{array}{r}\begin{array}{c}\text { Mainly } \\
\text { respondent }\end{array} \\
9\end{array}$} & \multirow{2}{*}{$\begin{array}{r}\begin{array}{c}\text { Mainly } \\
\text { husband, } \\
\text { partner }\end{array} \\
1\end{array}$} & \multirow{2}{*}{$\begin{array}{r}\begin{array}{c}\text { Joint } \\
\text { decision }\end{array} \\
10\end{array}$} & \multirow{2}{*}{$\begin{array}{r}\text { Other } \\
1\end{array}$} & \\
\hline & $n$ & & & & & \\
\hline \multirow[t]{3}{*}{$10-14$} & $\%$ within Age & $42.9 \%$ & $4.8 \%$ & $47.6 \%$ & $4.8 \%$ & $100.0 \%$ \\
\hline & $\%$ of Total & $2.0 \%$ & $0.2 \%$ & $2.2 \%$ & $0.2 \%$ & $4.7 \%$ \\
\hline & $\mathrm{n}$ & 100 & 8 & 98 & 0 & 206 \\
\hline \multirow{3}{*}{$15-19$} & $\%$ within Age & $48.5 \%$ & $3.9 \%$ & $47.6 \%$ & $0.0 \%$ & $100.0 \%$ \\
\hline & $\%$ of Total & $22.3 \%$ & $1.8 \%$ & $21.8 \%$ & $0.0 \%$ & $45.9 \%$ \\
\hline & $\mathrm{n}$ & 57 & 3 & 90 & 0 & 150 \\
\hline \multirow[t]{3}{*}{$20-24$} & $\%$ within Age & $38.0 \%$ & $2.0 \%$ & $60.0 \%$ & $0.0 \%$ & $100.0 \%$ \\
\hline & $\%$ of Total & $12.7 \%$ & $0.7 \%$ & $20.0 \%$ & $0.0 \%$ & $33.4 \%$ \\
\hline & $\mathrm{n}$ & 21 & 0 & 42 & 0 & 63 \\
\hline \multirow[t]{3}{*}{$25-29$} & $\%$ within Age & $33.3 \%$ & $0.0 \%$ & $66.7 \%$ & $0.0 \%$ & $100.0 \%$ \\
\hline & $\%$ of Total & $4.7 \%$ & $0.0 \%$ & $9.4 \%$ & $0.0 \%$ & $14.0 \%$ \\
\hline & $\mathrm{n}$ & 3 & 0 & 2 & 0 & 5 \\
\hline \multirow[t]{2}{*}{$30-34$} & $\%$ within Age & $60.0 \%$ & $0.0 \%$ & $40.0 \%$ & $0.0 \%$ & $100.0 \%$ \\
\hline & $\%$ of Total & $0.7 \%$ & $0.0 \%$ & $0.4 \%$ & $0.0 \%$ & $1.1 \%$ \\
\hline $35-39$ & n & 0 & 0 & 3 & 0 & 3 \\
\hline
\end{tabular}




\begin{tabular}{rlrrrrr} 
& $\%$ within Age & $0.0 \%$ & $0.0 \%$ & $100.0 \%$ & $0.0 \%$ & $100.0 \%$ \\
& $\%$ of Total & $0.0 \%$ & $0.0 \%$ & $0.7 \%$ & $0.0 \%$ & $0.7 \%$ \\
\hline \multirow{3}{*}{$40-44$} & $\mathrm{n}$ & 0 & 0 & 1 & 0 & 1 \\
& $\%$ within Age & $0.0 \%$ & $0.0 \%$ & $100.0 \%$ & $0.0 \%$ & $100.0 \%$ \\
& $\%$ of Total & $0.0 \%$ & $0.0 \%$ & $0.2 \%$ & $0.0 \%$ & $0.2 \%$ \\
\hline \multirow{3}{*}{ Total } & $\mathrm{n}$ & $\mathbf{1 9 0}$ & $\mathbf{1 2}$ & $\mathbf{2 4 6}$ & $\mathbf{1}$ & $\mathbf{4 4 9}$ \\
& $\%$ within Age & $42.3 \%$ & $2.7 \%$ & $54.8 \%$ & $0.2 \%$ & $100.0 \%$ \\
& \% of Total & $42.3 \%$ & $2.7 \%$ & $54.8 \%$ & $0.2 \%$ & $100.0 \%$ \\
\hline
\end{tabular}

*Weighted 1.14

Based on table 2, the highest percentage of decision-making using family planning is almost equal between the decision made by respondents themselves and joint decisions with their husbands (47\%-48\%), especially at the age of 10-14 years and 15-19 years. Furthermore, after the age of 34 years, all women of reproductive age $(100 \%)$ used joint decision in deciding their use of family planning approach.
Chi-square test for independence showed a significant relationship between the age of first sexual intercourse with decision making using $\mathrm{KB}, X^{2}(18, n=449)=36.06, p$ $=0.007$. Similar to the previous variable, the decision to use family planning has a statistically significant relationship (CI: 95\%). The association was moderate (Cramer's V $=0.16$ ).

Tabel 3. Knowledge about HIV/AIDS according to women's first age to have sex in 2017

\begin{tabular}{|c|c|c|c|c|}
\hline \multicolumn{2}{|c|}{ Age of first sexual intercourse } & \multicolumn{2}{|c|}{$\begin{array}{c}\text { Awareness about } \\
\text { HIV/AIDS }\end{array}$} & \multirow[t]{2}{*}{ Total } \\
\hline & & \multirow[t]{2}{*}{ Good } & Poor & \\
\hline & $\mathrm{n}$ & & 12 & 21 \\
\hline \multirow[t]{3}{*}{$10-14$} & $\%$ within Age & $42.9 \%$ & $57.1 \%$ & $100 \%$ \\
\hline & $\%$ of Total & $1.5 \%$ & $2.1 \%$ & $3.6 \%$ \\
\hline & $\mathrm{n}$ & 62 & 137 & 199 \\
\hline \multirow[t]{3}{*}{$15-19$} & $\%$ within Age & $31.2 \%$ & $68.8 \%$ & $100 \%$ \\
\hline & $\%$ of Total & $10.6 \%$ & $23.4 \%$ & $34.0 \%$ \\
\hline & $\mathrm{n}$ & 67 & 91 & 158 \\
\hline \multirow[t]{3}{*}{$20-24$} & $\%$ within Age & $42.4 \%$ & $57.6 \%$ & $100 \%$ \\
\hline & $\%$ of Total & $11.5 \%$ & $15.6 \%$ & $27.0 \%$ \\
\hline & $\mathrm{n}$ & 35 & 25 & 60 \\
\hline \multirow[t]{3}{*}{$25-29$} & $\%$ within Age & $58.3 \%$ & $41.7 \%$ & $10 ., 0 \%$ \\
\hline & $\%$ of Total & $6.0 \%$ & $4.3 \%$ & $10.3 \%$ \\
\hline & $\mathrm{n}$ & 3 & 3 & 6 \\
\hline \multirow[t]{3}{*}{$30-34$} & $\%$ within Age & $50.0 \%$ & $50.0 \%$ & $100 \%$ \\
\hline & $\%$ of Total & $0.5 \%$ & $0.5 \%$ & $1.0 \%$ \\
\hline & $\mathrm{n}$ & 1 & 2 & 3 \\
\hline \multirow[t]{2}{*}{$35-39$} & $\%$ within Age & $33.3 \%$ & $66.7 \%$ & $100 \%$ \\
\hline & $\%$ of Total & $0.2 \%$ & $0.3 \%$ & $0.5 \%$ \\
\hline
\end{tabular}


Sexual Behaviour and Reproductive Health of Women ... (Indriani, et.al)

\begin{tabular}{llrrr} 
& $\mathrm{n}$ & 1 & 1 & 2 \\
$40-44$ & \% within Age & $50.0 \%$ & $50.0 \%$ & $100 \%$ \\
& \% of Total & $0.2 \%$ & $0.2 \%$ & $0.3 \%$ \\
\hline \multirow{2}{*}{ Not having } & $\mathrm{n}$ & 51 & 85 & $\mathbf{1 3 6}$ \\
sex & $\%$ within Age & $37.5 \%$ & $62.5 \%$ & $100.0 \%$ \\
& \% of Total & $8.7 \%$ & $14.5 \%$ & $\mathbf{2 3 . 2 \%}$ \\
\hline \multirow{3}{*}{ Total } & $\mathrm{n}$ & $\mathbf{2 2 9}$ & $\mathbf{3 5 6}$ & $* \mathbf{5 8 5}$ \\
& $\%$ within Age & $39.1 \%$ & $60.9 \%$ & $100 \%$ \\
& \% of Total & $39.1 \%$ & $60.9 \%$ & $100 \%$ \\
\hline
\end{tabular}

*Weighted 1.08

Based on table 3, there were about $23 \%$ $(n=136)$ women of reproductive-aged 15-49 years old who recorded not having sex. It was found that approximately $60 \%$ of women of reproductive age who had less knowledge about HIV / AIDS. Importantly, among women aged 10-19 years old, approx. $60 \%$ have poor knowledge about HIV/AIDS transmission. Although the Chi-square test for independence showed a significant relationship between the age of first sexual intercourse with knowledge about HIV / AIDS, $X^{2}(7, n=585)=16.02, p=$ 0.025 . The confusion correlation was moderate (Cramer's V $=0.16$ ).

\section{DISCUSSIONS}

Overall, the results of this study identified $40 \%$ of sexually active women of reproductive age were in the 10-19 years age group. The study also identified marriages in this risky age group was 37\%, and among them, almost $4 \%$ were done before the age of 15 years. This finding indicates that not all women of reproductive age in the 10-19 years age group who are sexually active will enter marriage at that age period. According to Nsubuga., Sekandi., Sempeera. \& Makumbi (2016), the risk of pregnancy increases with increasing distance between first sexual intercourse and the age of first marriage. Berliana et al. (2018) said that women who have a long AFSI and FMA distance tend to be exposed to unsafe sexual activity.
This finding was in line with the conditions in several ASEAN countries. Studies showed that of 27 million adolescent girls aged $15-19$ years, $35 \%$ had been married, and $18 \%$ of them give birth were still under the age of 20 years (Yasukawa et al., 2017). Similar to the countries of Mali and Bangladesh, there were $25 \%$ of women of reproductive-aged 20 24 who had had sexual relations before the age of 15 years and $40 \%$ or more women aged 2024 in nine Latin American countries report having had sex before the age of 18 years (Chandra-mouli et al., 2014). Thus, the proportion of FMA in Indonesia is higher than in some ASEAN countries such as Cambodia, the Philippines, and Thailand, but lower than countries in Latin America.

The results of this study indicate a decrease in the number of women of reproductive age who did not experience pregnancy complications from 2012-2017. However, it was found that the incidence of pregnancy complications in women of reproductive age of 10-14 years was almost twice as significant as between the age of 20-24 years. The findings of this study are consistent with studies showing that adolescents who were becoming pregnant and give birth at age <19 years are twice as likely to die during pregnancy or childbirth as women aged 20 years or more (Berliana et al., 2018; WHO, 2018.) According to this source, complications during pregnancy and childbirth are the leading causes of the death of adolescents aged 15-19 years in the world. Importantly, for adolescents aged $<15$ years, the risk is five times greater 
(IPU, 2016; Nsubuga et al., 2016). Teenage mothers (10-19 years old) face a higher risk of developing eclampsia, puerperal endometritis, and systemic infections compared to women aged 20-24 years (BKKBN, 2017). Several studies showed that at that age, women are not ready physically, mentally, and socially to become mothers (WHO, 2019; Woog \& Kågesten, 2017). At this age, girls have not been able to exercise control over their own bodies, including their sexual and reproductive abilities (BPS \& UNICEF, 2016). In the mental aspect, various studies show that girls who marry at an early age are at high risk of experiencing anxiety, depression, or having thoughts of suicide (BPS, 2017).

Findings from this study indicate that the decision to have family planning was proportionally balanced between the decisions taken by the women of reproductive age themselves and those decided with a partner. This phenomenon showed that at the age of 1019 years old, women of reproductive age had to make an important decision in choosing the right contraception method (Akintuyi \& Fatusi, 2017). Decision making was strongly influenced by the knowledge and attitudes of the women of reproductive age themselves, the availability of facilities, tools, and source of information about family planning, as well as those who can encourage or strengthen their decision. Further studies showed that women of reproductive age and her partner/husband who were in this age group were both learning to find their role as teenagers in society (Gazzaniaga, M. S., Heathertone, T.F., Halpern, 2010). Thus, making decisions in the choice of contraception devices/methods was not an essential thing in life and difficult for them. They were still preoccupied with the search for identity, which was marked by the desire to experiment with many things (Gazzaniaga, M. S., Heathertone, T.F., Halpern, 2010). As a result, choosing contraception devices/methods were very likely to be inappropriate. To solve this problem globally, WHO (2018) issued recommendations to guarantee women's human rights to obtain family planning information and services. Thus, adolescent mothers can get sufficient information before deciding on a decision to use contraception methods/methods that are appropriate for teenage mothers.

The results show that there were approx. $60 \%$ of women 15-49 years of age had poor knowledge about HIV/AIDS. This number was higher $17 \%$ than the result found by Ma'ruf and Phuengsamran, (2016), who found $42.5 \%$ of women aged 18-40 years old have no comprehensive knowledge of AIDS. Compared to another region in Indonesia, a higher proportion $(70 \%)$ of women $18-40$ years of age in Lampung had poor knowledge of HIV/AIDS (Irmayati et al., 2019). Although the association was weak, the relationship first sexual intercourse and knowledge about HIV/AIDS to reach significance. Good knowledge, according to Sitohang, (2017) associated with the utilization of behavior prevention mother to child HIV transmission programs. Therefore, poor knowledge among these groups of women may increase the risk of mother to child HIV transmission.

The findings in this study confirm that the use of the Precede Model and Procedure is in accordance with the research objectives. Three of the five reproductive health features of women of reproductive-aged 15-49 years old reached significance level $(\alpha<0.05)$, including 1). pregnancy complications, 2). decision making about family planning. Two of them had not reached the level of significance (4). knowledge about HIV/AIDS and 5) knowledge about family planning tools/methods).

The Precede and Proceed models work as an open system that is strongly influenced by the internal and external environment. Furthermore, as a system, the results of impact evaluations and results can again be input, can be used to determine an appropriate plan of response efforts. In this system, the information was obtained from the 1-3 assessment phase (social, epidemiological assessment, and education and environmental assessment). In this study, the five reproductive health features of women of reproductive age can be explained 
into predisposing, enabling, and reinforcing factors.

Factors predisposition in this study were complications of pregnancy and early sexual behavior. For this reason, efforts can be made to improve the health status of women of reproductive age. Efforts, education, and health services were supported in the enabling factors are needed. Furthermore, the enabling factors in this research were knowledge about HIV/AIDS and knowledge about family planning. The last factor was the reinforcing factor, namely the decision making about family planning and the reasons for stopping using contraception methods/methods. Focusing on these three determinant factors will facilitate stakeholders such as government, health care institutions, education institutions, and other institutions in developing more contextualized reproductive health programs that are in accordance with the current needs.

In order to improve young women's sexual behavior, some strategies have been conducted globally and locally. WHO (2018) has developed evidence-based guidelines in six areas to improve reproductive health prevention of early marriage; prevention of early pregnancy through sexual education; school opportunity improvement programs and economic and social support programs; increased use of contraception, reducing sexual violence, preventing unsafe abortion; and improve health care services in the prenatal and postnatal period. Furthermore, the National Population and Family Planning (BKKBN) (Badan Kependudukan Dan Keluarga Berencana Nasional, 2015) has made several national programs to improve women's reproductive health. For example, the Adolescent Health Care Services (PKPR) program, with specific characteristics in counseling services and enhancing adolescent's ability to apply Education and Healthy Life Skills (PKHS) has been implemented. These programs are carried out in an integrated manner in health centers, hospitals, youth clubs, churches, or places where young people gather. In addition, the Generasi Planning (GenRe) program is organized by $\mathrm{BKKBN}$ targeting young people and families who have teenagers. Activities initiated by the Youth / Student Information and Counseling Center (PIK R/M). At the family level, the Youth Resilience Development (BKR) group was developed.

Even though these strategies have been employed, issues about sexual behaviors and reproductive health, especially in North Sulawesi Province, are still emergent. Therefore, it is argued that we need more intensive and innovative strategies to overcome the problems. Implementation of the programs needs to be culturally sensitive. Meaning that the strategy developed is relevant to their sociocultural aspects such as age, educational background, values, and so on. Importantly, teachers, parents, and adults who are responsible for providing the knowledge must have comprehensive sexual education knowledge and strategies. By doing these, we will be able to accelerate women's reproductive health and therefore achieve Indonesia's health goals by 2030 .

\section{CONCLUSIONS}

This study revealed a significant relationship between sexual behavior, the age of first sexual intercourse with pregnancy complications, decision making about the use of contraception, and knowledge about HIV/AIDS. The relationship between early sexual intercourse with the reason to stop using family planning and knowledge about family planning did not reach the level of significance. The results of this study show that $40 \%$ of all sexually active women were aged 10-19 years old. This study also identified that women mostly decided on the chosen family planning methods. The decision might not be in accordance with rational family planning. It was found that a low proportion of women of reproductive age understood about HIV transmission. Furthermore, the findings on the aspects of knowledge about family planning did not provide meaningful information because the knowledge about modern and traditional 
family planning had not demonstrated the quality of respondents' knowledge about family planning tools/methods that were known.

In accordance with the findings in the study, some suggested ideas for improving the reproductive health of women of reproductive age are as follows. First, BKKBN of North Sulawesi Province needs to employ culturally sensitive approaches in adapting the six guidelines for improving reproductive health. Second, make more intensive action plans by involving partners in developing reproductive health programs with health service institutions, educational institutions, community, and religious leaders. Third, socialize these programs to the public through school programs, religious groups' activities, and other communities' programs. Fourth, prepare at least six reproductive health education modules that meet WHO standards (WHO, 2018) that are tailored to the needs of the community. For example, reproductive health modules for primary school children are distinguished from modules for middle and higher school children. Fifth, provide reproductive health education programs for parents, teachers, and religious leaders. Finally, integrate better strategies to gain better practical knowledge about reproductive health, starting from the basic education curriculum in primary school. This work was supported by The National Population and Family Planning (grant numbers: 02/SPK/KU.02.01/H3/2019).

\section{REFERENCES}

Akintuyi, A. F., \& Fatusi, A. (2017). Sexual experience and pattern of contraceptives use among in-school Adolescents in Akure, Nigeria. International Journal of Biological \& Medical Research, 8(2), 5979-5985. www.biomedscidirect.com

Badan Kependudukan Dan Keluarga Berencana Nasiona. (2015). Rencana Strategis Badan Kependudukan Dan Keluarga Berencana Nasional. Bkkbn, 2019 ,

$1-43$.
https://doi.org/10.1017/CBO9781107415 324.004

Badan Pusat Statistik, \& UNICEF. (2016). Analisis Data Perkawinan Usia Anak di Indonesia. In Unicef Indonesia (Issue Analisis Data Perkawinan). https://doi.org/978-978-064-963-6

Berliana, S. M., Utami, E. D., Efendi, F., \& Kurniati, A. (2018). Premarital Sex Initiation and the Time Interval to First Marriage Among Indonesians. Bulletin of Indonesian Economic Studies, 54(2), 215-232.

https://doi.org/10.1080/00074918.2018.1 440067

BKKBN. (2012). Survei Demografi dan Kesehatan Indonesia 2012.

BKKBN. (2017). Survei Demografi dan Kesehatan Indonesia 2017. In Badan Kependudukan dan Keluarga Berencana. http://sdki.bkkbn.go.id/files/buku/2017ID HS.pdf

BPS. (2017). Perkawinan Usia Anak di Indonesia. The British Journal of Psychiatry, 112(483), 211-212. https://doi.org/10.1192/bjp.112.483.211a

Chandra-mouli, V., Mccarraher, D. R., Phillips, S. J., \& Williamson, N. E. (2014). Contraception for adolescents: Social, clinical and service delivery considerations Contraception for adolescents in low and middle income countries: needs, barriers, and access. Reproductive Health, 11(1), 1-8. https://doi.org/10.1016/S00207292(01)00371-X

Dinkes. (2015). Profil Kesehatan Dinas Kesehatan Provinsi Sulawesi Utara 2015.

Djamilah, D., K. (2015). Dampak Perkawinan Anak di Indonesia. Jurnal Studi Pemuda, 3(1), 1-16.

Finner, LB., \& Philibin, J. . (2013). Sexual 
Initiation, Contraceptive Use, and pregnancy Among Young Adolescent. Pediatrics, 131(5), 886-891.

Gazzaniaga, M. S., Heathertone, T.F., Halpern, D. F. (2010). Psychological Science (3rd ed.). W.W. Norton \& Company, Inc.

Harnan., Marlian., K. (2019). Teori Kesehatan Reproduksi. Deepublish.

InfoDaTin. (2015). Situasi Kesehatan Reproduksi Remaja.

IPU, W. (2016). Child, Early and forced marriage legislationin 37 Asia-Pacific countries.

Irmayati, N., Yona, S., \& Waluyo, A. (2019). HIV-related stigma, knowledge about HIV, HIV risk behavior and HIV testing motivation among women in Lampung, Indonesia. Enfermeria Clinica, 29(xx), 546-550.

https://doi.org/10.1016/j.enfcli.2019.04.0 84

Ma'ruf, M. A., \& Phuengsamran, D. (2016). Association between HIV-AIDS related knowledge and HIV-AIDS related behavior among urban young adult men in Indonesia. Asian Academic Society International Conference Proceeding Series, $\quad 0(0), \quad 301-307$. http://aasic.org/proc/aasic/article/view/18 $8 / 185$

MacPhail, C., Pettifor, A. E., Pascoe, S., \& Rees, H. V. (2007). Contraception use and pregnancy among 15-24 year old South African women: A nationally representative cross-sectional survey. BMC Medicine, 5, 1-8. https://doi.org/10.1186/1741-7015-5-31

Nsubuga, H., Sekandi, J. N., Sempeera, H., \& Makumbi, F. E. (2016). Contraceptive use, knowledge, attitude, perceptions and sexual behavior among female University students in Uganda: A cross-sectional survey. BMC Women's Health, 16(1), 111. https://doi.org/10.1186/s12905-016-
0286-6

Nugraheni, S. A., . M., Kartasurya, M. I., Prihatini, I. J., \& Sulistyowati, E. (2018). Knowledge and attitudes about reproductive health and pregnancy preparedness: preliminary study of brides and grooms in Brebes district, Central Java, Indonesia. International Journal of Community Medicine And Public Health, $5(6)$, 2170. https://doi.org/10.18203/23946040.ijcmph20181970

Pallant, J. . (2014). SPSS survival manual: A step by step guide to data analysis using IBM SPSS. Allen \& Unwin.

Sitohang, M. Y. (2017). Utilization Factors of Prevention Mother to Child HIV Transmission (PMTCT) Program Among Pregnant Women. Journal of Indonesian Social Sciences and Humanities, 7(2), 107-118. https://doi.org/10.14203/jissh.v7i2.144

Wattimena, J. C., Black, K., \& Bernays, S. (2020). 223. "Make all Health Services Youth Friendly": A Qualitative Study Exploring the Provision of Sexual and Reproductive Health Care for Young Women in Maluku, Indonesia. Journal of Adolescent Health, 66(2), S113. https://doi.org/10.1016/j.jadohealth.2019. 11.226

WHO. (n.d.). Adolescent pregnancy fact-sheet. 2018. https://www.who.int/en/newsroom/fact-sheets/detail/adolescentpregnancy

WHO. (2018). Adolescent pregnancy factsheet.

Woog, V., \& Kågesten, A. (2017). The Sexual and Reproductive Health Needs of Very Young Adolescents In Developing Countries. Guttmarcher Institute, May, 10-11. https://www.guttmacher.org/factsheet/srh-needs-very-young-adolescentsin-developing-countries 
Jurnal INJEC Vol. 5 No. 1 June 2020: 15-26

Yasukawa, K., Hamilton, M., \& Evans, J. (2017). A comparative analysis of national media responses to the OECD Survey of Adult Skills: policy making from the global to the local? Compare, $47(2)$,

271-285. https://doi.org/10.1080/03057925.2016.1 158644 